\title{
The Most Frequently Read Practice-based Research (PBR) Articles in the Journal of the American Board of Family Medicine (JABFM)
}

\author{
Phillip Lupo, Jr., MLIS, Anne Victoria Neale, PhD, MPH, and
} Marjorie A. Bowman, MD, MPA

Here, as part of our $10^{\text {th }}$ annual Practice-based Research (PBR) issue, the fournal of the American Board of Family Medicine ( $7 A B F M)$ is pleased to provide a cumulative report of published PBR articles that hold the

Conflict of interest: The authors are editors and staff of the JABFM. greatest interest for our readers. Table 1 shows the top 20 most-read PBR articles in the $7 A B F M$. The access events present in Table 1 include article hits and downloads. The data are cumulative from the date of publication to June 2015 .

Table 1. The Top 20 Most Frequently Read Practice-based Research (PBR) Articles appearing in the Journal of the American Board of Family Medicine (JABFM) special practice-based research (PBR) issues

\footnotetext{
1. Family Medicine Patients' Use of the Internet for Health Information: A MetroNet Study. (22,886 accesses): http:// jabfm.org/content/19/1/39.full (1)

2. Quasi-Experimental Designs in Practice-based Research Settings: Design and Implementation Considerations. (21,809 accesses): http://jabfm.org/content/24/5/589.full (2)

3. A Short History of Primary Care Practice-based Research Networks: From Concept to Essential Research Laboratories. (18,927 accesses): http://jabfm.org/content/19/1/1.full (3)

4. Management of Prescription Refills in Primary Care: An Oklahoma Physicians Resource/Research Network (OKPRN) Study. (18,733 accesses): http://jabfm.org/content/19/1/31.full (4)

5. High Blood Pressure Knowledge Among Primary Care Patients with Known Hypertension: A North Carolina Family Medicine Research Network (NC-FM-RN) Study. (15,378 accesses): http://jabfm.org/content/21/4/300.full (5)

6. Comparison of Point of Care and Laboratory HbA1c Analysis: A MetroNet Study. (14,067 accesses): http://jabfm.org/ content/22/4/461.full (6)

7. Primary Care Physicians' Knowledge and Practice Patterns in the Treatment of Chronic Kidney Disease: An Upstate New York Practice-based Research Network (UNYNET) Study. (12,105 accesses): http://jabfm.org/content/19/1/54.full (7)

8. The Prevalence of Dysphagia in Primary Care Patients: A HamesNet Research Network Study. (11,810 accesses): http://jabfm.org/content/20/2/144.full (8)

9. How Can Practice-based Research Contribute to the Elimination of Health Disparities? (11,494 accesses): http://jabfm.org/content/20/2/105.full (9)

10. Family Physician's Knowledge, Beliefs, and Self-reported Practice Patterns Regarding Hyperlipidemia: A National Research Network (NRN) Survey. (10,859 accesses): http://jabfm.org/content/19/1/46.full (10)

11. Barriers and Motivators for Making Error Reports from Family Medicine Offices: A Report from the American Academy of Family Physicians National Research Network (AAFP NRN). (10,590 accesses): http://jabfm.org/content/ 20/2/115.full (11)

12. A Logic Model Framework for Evaluation and Planning in a Primary Care Practice-based Research Network (PBRN). (9,811 accesses): http://jabfm.org/content/24/5/576.full (12)

13. Implementing and Evaluating Electronic Standing Orders in Primary Care Practice: A PPRNet Study. (9,534 accesses): http://jabfm.org/content/25/5/594.full (13)

14. Pharmacy Clarification of Prescriptions Ordered in Primary Care: A Report from the Applied Strategies for Improving Patient Safety (ASIPS) Collaborative. (9,417 accesses): http://jabfm.org/content/19/1/24.full (14)

15. Poor Nutritional Habits: A Modifiable Predecessor of Chronic Illness? A North Carolina Family Medicine Research Network (NC-FM-RN) Study. (9,195 accesses): http://jabfm.org/content/20/2/124.full (15)

16. Barriers, Enablers, and Incentives for Research Participation: A Report from the Ambulatory Care Research Network (ACRN). (9,086 accesses): http://jabfm.org/content/22/4/436.full (16)
} 
Data source: Access statistics for the $7 A B F M$ are cumulative from the date of publication, HighWire Press (updated monthly). Accessed June 22, 2015.

\section{References}

1. Schwartz KL, Roe T, Northrup J, et al. Family medicine patients' use of the internet for health information: a MetroNet study. J Am Board Fam Med; 2006;19:39-45.

2. Handley MA, Schillinger D, Shiboski S. Quasi-experimental designs in practice-based research settings: design and implementation considerations. J Am Board Fam Med; 2011;24:589-96.

3. Green LA, Hickner J. A short history of primary care practice-based research networks: from concept to essential research laboratories. J Am Board Fam Med; 2006;19: $1-10$.

4. Ferrell CW, Aspy CB, Mold JW. Management of prescription refills in primary care: an Oklahoma Physicians Resource/Research Network (OKPRN) study. J Am Board Fam Med; 2006;19:31-8.

5. Viera AJ, Cohen LW, Mitchell CM, et al. High blood pressure knowledge among primary care patients with known hypertension: a North Carolina Fam Med Research Network (NC-FM-RN) study. J Am Board Fam Med; 2008;21:300-8.

6. Schwartz KL, Monsur J, Hammad A, et al. Comparison of point of care and laboratory HbAlc analysis: a MetroNet study. J Am Board Fam Med; 2009;22:461-3.

7. Fox CH, Brooks A, Zayas LE, et al. Primary care physicians' knowledge and practice patterns in the treatment of chronic kidney disease: an Upstate New York Practice-based Research Network (UNYNET) study. J Am Board Fam Med; 2006;19:54-61.

8. Wilkins T, Gillies RA, Thomas AM, et al. The prevalence of dysphagia in primary care patients: a HamesNet research network study. J Am Board Fam Med; 2007;20: 144-50.

9. Rust G, Cooper LA. How can practice-based research contribute to the elimination of health disparities? J Am Board Fam Med; 2007;20:105-14.

10. Eaton CB, Galliher JM, McBride PE, et al. Family physician's knowledge, beliefs, and self-reported practice patterns regarding hyperlipidemia: a $\mathrm{Na}$ tional Research Network (NRN) survey. J Am Board Fam Med; 2006;19:46-53.

11. Elder NC, Graham D, Brandt E, et al. Barriers and motivators for making error reports from family medicine offices: a report from the American Academy of
Family Physicians National Research Network (AAFP NRN). J Am Board Fam Med; 2007;20:115-23.

12. Hayes H, Parchman ML, Howard R. A logic model framework for evaluation and planning in a primary care practice-based research network (PBRN). J Am Board Fam Med; 2011;24:576-82.

13. Nemeth LS, Ornstein SM, Jenkins RG, et al. Implementing and evaluating electronic standing orders in primary care practice: a PPRNet study. J Am Board Fam Med; 2012;25:594-604.

14. Hansen LB, Fernald D, Araya-Guerra R, et al. Pharmacy clarification of prescriptions ordered in primary care: a report from the Applied Strategies for Improving Patient Safety (ASIPS) collaborative. J Am Board Fam Med; 2006;19:24-30.

15. Gaskins ND, Sloane PD, Mitchell CM, et al. Poor nutritional habits: a modifiable predecessor of chronic illness? A North Carolina Fam Med Research Network (NC-FM-RN) study. J Am Board Fam Med; 2007;20:124-34.

16. Bakken S, Lantigua RA, Busacca LV, et al. Barriers, enablers, and incentives for research participation: a report from the Ambulatory Care Research Network (ACRN). J Am Board Fam Med; 2009;22:436-45.

17. DeVoe JE, Gold R, Spofford M, et al. Developing a network of community health centers with a common electronic health record: description of the Safety Net West Practice-based Research Network (SNW-PBRN). J Am Board Fam Med; 2011;24:597-604.

18. Forcade NA, Parchman ML, Jorgensen JH, et al. Prevalence, severity, and treatment of communityacquired methicillin-resistant stapbylococcus aureus (CA-MRSA) skin and soft tissue infections in 10 medical clinics in Texas: a South Texas Ambulatory Research Network (STARNet) study. J Am Board Fam Med; 2011;24:543-50.

19. Fontaine P, Mendenhall TJ, Peterson K, et al. The "Measuring Outcomes of Clinical Connectivity" (MOCC) trial: investigating data entry errors in the Electronic Primary Care Research Network (ePCRN). J Am Board Fam Med; 2007;20:151-9.

20. Westfall JM, Fagnan LJ, Handley M, et al. Practicebased research is community engagement. J Am Board Fam Med; 2009;22:423-7. 